UDC: 351.342

DOI: https://doi.org/10.32689/26172224-2019-17-2-85-94

\section{Karpyuk Sergey Vasilievich,} graduate student, Interregional Academy of Personnel Management, 03039, Kyiv, Str. Frometivska, 2, tel.: (097) 76868 41, e-mail: Sergei.karpjuk@meta.ua

ORCID: 0000-0002-7579-4867

\section{Карпюк Сергій Васильович,}

аспірант, Міжрегіональної Академіїуправління персоналом, 03039 м. Київ, вул. Фрометівська, 2, тел.: (097) 76868 41, е-таil: Sergei.karpjuk@meta.ua

ORCID: 0000-0002-7579-4867

Карпюк Сергей Васильевич,

аспирант, Межрегиональная Академия управления персоналом, 03039, г. Киев, ул. Фрометовская, 2, тел.: (097) 7686841 , e-mail: Sergei.karpjuk@meta.ua

ORCID: 0000-0002-7579-4867

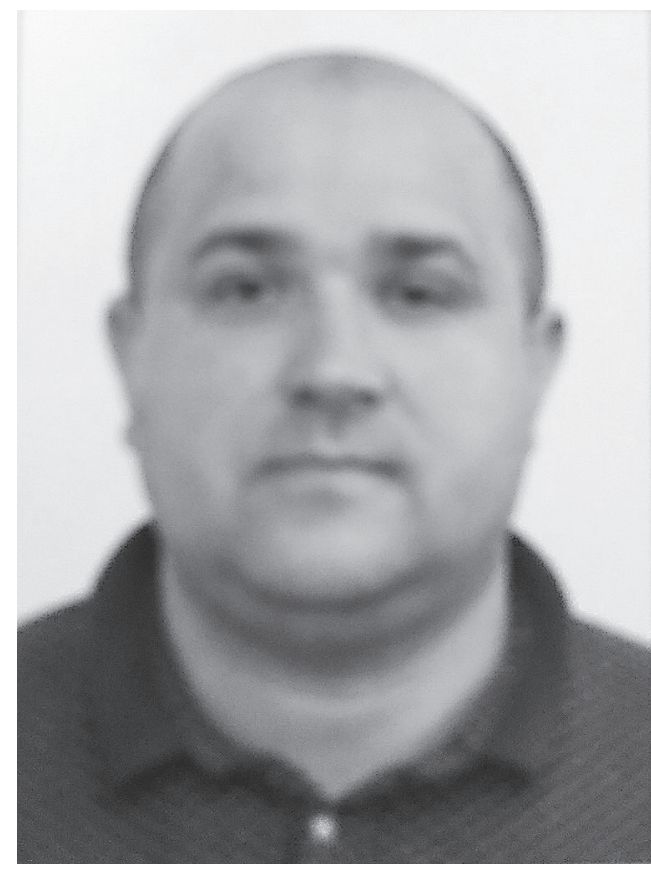

\title{
ACTUAL THEORETIKO-METHODOLOGICAL ASPECTS OF RESEARCH OF THE PHENOMENON "STATE ADMINISTRATION" IN PARADIGM OF DEVELOPMENT OF MODERN PUBLIC ADMINISTRATION
}

\begin{abstract}
Such basic theoretical concepts of the system of state administration as "state", "state administration", "government service", "public management", "public administration", "state-administrative elite are examined". Attention applies on that, one hundred the problems of transformation of government service are above all things conditioned radical transformations of the state and embarks on basis that the state in general all anymore will be examined exactly as a specific instrument (method, mechanism) of organization of functioning of sociuma. It is underlined that state administration has an own specific and in a greater degree depends on the degree of development of society. A thesis is grounded in relation to that state administration is a specific type of activity of organs of the state, which is carried out by means of two types of such activity - executive and active and has an organizing influence in three public spheres - economic, social'nokul'turnoy and administrative. Specified on that government service, as difficult
\end{abstract}


social phenomenon, can be examined as governmental service and as service civil. Attention applies on that in most cases government service is explained and as activity professional, that it is carried out by specially geared-up specialists. It is thus impossible to unite the phenomena "civil servants" and "bureaucracy", which have different sense and explanation. The substantial features of concepts "Public management" and "public administration", "state-administrative elite, are analysed". It is underlined that government service must be considerable appearance by depolitizirovannoy, professional activity.

It is substantiated that since the public service is carried out by specially selected, professionally trained employees, civil servants, the following general remarks should be made: often when considering various aspects of the civil service, the term "state apparatus" is used. In fact, it should be borne in mind that this term has two main meanings: a) as a certain organizational structure; b) as a personnel structure of a certain structure in the system of civil service. We believe that the second meaning is more precise and concrete.

Keywords: state, state administration, government service, public management, public administration, state-administrative elite.

\section{АКТУАЛЬНІ ТЕОРЕТИКО-МЕТОДОЛОГІЧНІ АСПЕКТИ ДОСЛІДЖЕННЯ ФЕНОМЕНУ “ДЕРЖАВНЕ УПРАВЛІННЯ”$$
\text { В ПАРАДИГМІ РОЗВИТКУ СУЧАСНОГО }
$$ ПУБЛІЧНОГО АДМІНІСТРУВАННЯ}

Анотація. Розглядаються такі основоположні теоретичні поняття системи державного управління як “держава”, “державне управління”, “державна служба”, “публічне управління”, “публічне адміністрування”, “державно-управлінська еліта”. Звертається увага на те, що проблеми трансформації державної служби насамперед зумовлені радикальними трансформаціями самої держави і береться за основу те, що держава в майбутньому все більше буде розглядатися саме як специфічний інструмент (засіб, механізм) організації функціонування соціуму. Підкреслюється, що державне управління має власну специфіку і значною мірою залежить від особливостей суспільного розвитку. Обгрунтовується теза стосовно того, що державне управління - це специфічний вид діяльності органів держави, який здійснюється за двома видами - виконавчим і розпорядчим, та має організуючий вплив насамперед у трьох суспільних сферах - економічній, соціально-культурній та адміністративній. Зазначається, що державна служба як складний соціальний феномен може розглядатися як урядова служба і як служба громадянська. Звертається увага на те, що у більшості випадків державну службу пояснюють як діяльність професійну, тобто її здійснюють спеціально відібрані й професійно підготовлені фахівці. При цьому слід не поєднувати феномени “державні службовці” і “бюрократія”, які мають різний сенс і пояснення. Аналізуються сутнісні значення понять “публічне управління” і “публічне адміністрування”, “державно-управлінська еліта”. Підкреслюється, що державна служба має бути значною мірою деполітизованою, професійною діяльністю. 
Обгрунтовано: оскільки державна служба виконується спеціально підібраними, професійно підготовленими працівниками, державними службовцями, то під час розгляду різних аспектів державної служби доречно вжити термін “державний апарат”. Фактично слід брати до уваги саме те, що такий термін має два основних значення: а) як певна організаційна структура; б) як кадровий склад певної структури в системі державної служби. Вважаємо, що друге значення є більш точним і конкретним.

Ключові слова: держава, державне управління, державна служба, публічне управління, публічне адміністрування, державно-управлінська еліта.

\section{АКТУАЛЬНЫЕ ТЕОРЕТИКО-МЕТОДОЛОГИЧЕСКИЕ АСПЕКТЫ ИССЛЕДОВАНИЯ ФЕНОМЕНА “ГОСУДАРСТВЕННОЕ УПРАВЛЕНИЕ” В ПАРАДИГМЕ РАЗВИТИЯ СОВРЕМЕННОГО ПУБЛИЧНОГО АДМИНИСТРИРОВАНИЯ}

Аннотация. Рассматриваются такие основоположные теоретические понятия системы государственного управления как “государство”, “государственное управление”, “государственная служба”, “публичное управление”, "публичное администрирование", “государственно-управленческая элита". Обращается внимание на то, что проблемы трансформации государственной службы в первую очередь обусловлены радикальными трансформациями самого государства и берется за основу то, что государство в общем все больше будет рассматриваться именно как специфический инструмент (способ, механизм) организации функционирования социума. Подчеркивается, что государственное управление имеет собственную специфику и в большей степени зависит от степени развития общества. Обосновывается тезис относительно того, что государственное управление - это специфический вид деятельности органов государства, который осуществляется посредством двух видов такой деятельности - исполнительная и распорядительная и имеет организующее влияние в трех общественных сферах - экономической, социально-культурной и административной. Указывается на то, что государственная служба как сложный социальный феномен может рассматриваться как правительственная служба и как служба гражданская. Обращается внимание на то, что в большинстве случаев государственную службу объясняют и как деятельность профессиональную, то есть ее осуществляют специально подготовленные специалисты. При этом нельзя объединять феномены “государственные служащие” и “бюрократия”, которые имеют различный смысл и объяснение. Анализируются существенные особенности понятий “публичное управление” и “публичное администрирование”, “государственно-управленческая элита”. Подчеркивается, что государственная служба должна быть значительным образом деполитизированной, профессиональной деятельностью.

Обосновано: поскольку государственная служба выполняется специально подобранными, профессионально подготовленными работниками, государственными служащими, то при рассмотрении различных аспектов государ- 
ственной службы следует употреблять термин “государственный аппарат”. Фактически следует принимать во внимание именно то, что такой срок имеет два основных значения: а) как определенная организационная структура; б) как кадровый состав определенной структуры в системе государственной службы. Считаем, что второе значение является более точным и конкретным.

Ключевые слова: государство, государственное управление, государственная служба, публичное управление, публичное администрирование, государственно-управленческая элита.

Problem statement. Public administration, as a scientific branch, exists in many countries recently. In Ukraine, for example, it appeared only in 1997, when in a special Resolution of the Cabinet of Ministers of Ukraine in the list of scientific degrees and titles of doctor and candidate of Sciences the entry "public administration" appeared. In this regard, the scientific and theoretical understanding of the essence of this concept, the concepts that primarily justify it, have a considerable relevance.

Analysis of recent research and publications. Taking into account the works of such famous foreign scientists as V. Ardov, G. Atamanchuk, K. Bowman, T. Veblen, E. Voutilainen, U. Hamilton, M. Dewan, J. Ivatsevich, A. Kempinski, D. Kendrick, T. Kono, K. Kunz, Marr, M. Meskon, D. North, A. Rybakov, Yu. Schmidt and others, Ukrainian - A. Borovska, O. Buhtatii, N. Dragomirecka. V. Kniaziev, V. Kozakov, V. Lipkan, A. Radchenko, Ye. Romanenko, A. Parkhomenko-Kutsevol, N. Nyzhnyk, V. V. Obolenskyi, V. Rybalko, G. Shchokin, etc., it is possible to distinguish (according to the author) the range of problems of theoretical research of the phenomenon of "governance", which is defined such basic notions as "state" (modern); "public administration"; "public service"; "public management"; "public-managerial elite".

The purpose of the article is to analyze the current theoretical and methodological aspects of the study of the phenomenon of "public administration" in the development of modern public administration

Presentation of the main material of the study. The given list of terms (maxims) seems to us to be the main one - others are largely derived from the above.

Further, since each of the above concepts requires a thorough and comprehensive study, we will define and point out only those important components and features that are insufficiently studied in the state government, or in general have affected seriously recently.

State. As a human formation, as a mechanism of association of large groups of people in society for living together, modern states are quite radically transformed. So, in the future, quite objectively, the demands of citizens and society regarding the capacity of the state will grow. Many states are no longer able to really ensure the rights and freedoms of a person (citizen), and therefore in the future we will most likely observe a noticeable rejection of 
a purely liberal model of its functioning. The state will be increasingly seen as a specific tool (means, mechanism) of the organization of the functioning of society. Therefore, public administration, activity of civil servants, their relations with society will fundamentally change.

Public administration. Reflecting on the fate of governance as a whole and this has a direct relation to the public administration - the well-known Russian expert in the field of public administration G. V. Atamanchuk notes that the management system will eventually increasingly gravitate to its own renewal, improvement. He writes: "It is not difficult to see a certain relationship between the state and potential of management, on the one hand, and the dynamics of development of a society, on the other hand. Where the management "naps" or is helpless, there the society in all its spheres is in stagnation, collapse, conflict, underdevelopment and neglect" [1, p. 73]. And he warns: "Here it is important to make a breakthrough, not a break of chain of historical development, the rejection of the previous culture, the collapse created over the centuries" [1, p. 79]. In this case, we have to warn that the historical, theoretical and practical developments, including in the field of public administration in Ukraine, even in the so-called Soviet era, can not be absolutely negative: it is necessary to think over such a practice with the desire to borrow the best elements that can serve as a positive today.

In the basis of the analysis of public administration, public service there should be an understanding that the state generally, by definition of
S. Kurits and V. Vorobyov, "is one of the types of systems of nature, but the organization created by people (organizational system) that is an artifact" [2, p. 70]. One of the founders of cybernetics N. Wiener wrote on this mater: "Nature, in the broadest sense of the word, can and should serve not only as a source of tasks that I solve, but it indicated to the apparatus that is convenient for their solution" [3, p. 44].

Public administration, as a specific type of activity of state bodies, in the vast majority of cases today is theoretically served through two main types of such activities: executive and administrative. They both provide an organizing influence on the social relations actually in three spheres - economic, socio-cultural and administrative [4, p. 147]. Public administration, in addition, is characterized by all the features of the executive power, and it is aimed mainly at the implementation of laws, other normative legal acts, ensuring sustainable social development.

There are grounds to assert that in modern Ukraine a fundamentally new paradigm of public administration is being formed, the most important components of which are the management culture of civil servants and the development of their value-oriented communication. Such components are logically defined in the Law of Ukraine "On public service" (10.12.2015), in "General rules of ethical behavior of SS", approved by the order of the National Agency of Ukraine on public service (05.08.2016). In addition, the relevant standards of public service are prescribed in the "Rules of ethical behavior of civil servants" (approved by 
the Cabinet of Ministers of Ukraine № 65 (11.02.2016).

Public service. Here it is necessary to refer to the opinion of the famous Russian political scientist V. F. Khalipov, who explained this phenomenon in two main ways: a) as a government service; b) as a civil service [5, p. 476]. Such interpretations of the concept of "public service" began to take shape in the era of educational absolutism (XVIII century). At that time, the idea that public service is no longer a service to the Tsar (autocrat, monarch) but to the state and, therefore, to society began to be formed and gradually dominated. The understanding of the phenomenon of "civil servant" (civil/ public servant; government official) changed adequately to this It meant that this servant is someone who works in the public authorities [5, p. 480].

We believe that we should not simply combine, embody the "public service" and "state bureaucracy", as, in particular, the authors of the textbook "Legal aspects of school management" (K, 2016). L. Pavlenko and V. V. Pavlenko [6] do. It should not be done at least because "public service" - is professional and responsible activity in public bodies, and "bureaucracy" - a "governing of functionaries", "power of (French - Burean) offices-institutions", that is, "bureaucracy" is mainly understood and explained as a kind of negative substance.

Along with state managers, who are often associated with bureaucracy, there is also a kind of social stratum called technocracy. According to the French researcher M. Ferro, this social layer in the twentieth century to some extent merged with the administration.
"If in the West, - Ferro writes, - bureaucracy provided functioning of the system, which served as an obstacle to various changes independent of the political and social conjuncture, in the USSR, on the contrary, it was increasingly identified with the political power, which, however, accused it of the same sins, and public opinion, attacking the bureaucracy, criticized the regime and the system as a whole" [7, p. 357]. On this occasion, the Russian scientist L. Karpinski very aptly expressed his opinion, he stated that in the Soviet era "bureaucracy got together with the state unrestricted access to management of the economy and culture that penetrated virtually all spheres of human life" [7, p. 361]. Back in 1941, D. Berchem in his book "the revolution of managers" claimed that technocrats (managers) have become a reality, and penetrated into public administration. This is another aspect of the problem.

When analyzing the practical activities of civil servants, the most important thing, we believe, is to take into account the fact that public administration (in which such employees operate) is one of the varieties of social management, more precisely - the management of people. Here we should fully agree with the opinion of the wellknown American political scientist, F. Fukuyama that the new management as a phenomenon in general, will be characterized by a significant increase in public administration. Another thing is that such management, over time, will have fundamentally different features, characteristics, content.

Public administration. The publicity of public service is one of the central concepts in public administration, 
which is explained very ambiguously. Thus, publicity in general is often explained simply by associating it with publicity [8]. Indeed, a number of researchers rightly argued that publicity and openness, according to, in particular S. Fedorov, as a tool for the implementation of publicity [9, p. 964-968].

Second. "Publicity", as a broader concept than "free speech", is a direct tool for a close combination of state power and civil society. Without such a combination, the state power is unlikely to be able to implement itself, and it is difficult to hope for the level of conscious support of the citizens of the state power.

The rather optimal definition of the phenomenon of "publicity" in the public service is complicated by the fact that such publicity is often considered in a particular sphere of economic activity. So, if we are talking about publicity in the field of socio-economic, economic (business) activities, we are talking about the accessibility of citizens to the actual knowledge of the activities of business structures (open business) [10, p. 275].

According to the above situation (different "understanding" of the term "publicity", we find it appropriate to consider it in the context of the term "public administration"). It is known that it was first used by the famous English researcher D. Keeling, who understood it as the "search for the best ways to use resources to achieve the priority goals of the state" [11, p. 605].

The confirmation of this definition is found in a number of documents of normative nature of the state level, which were adopted in modern Ukraine. Thus, in article 45 of the new edition of the Law of Ukraine "On public service" (2015) the publicity of public service is fixed by the following mandatory conditions of its practical functioning as: public reports of heads of executive authorities to the public on the activities of a particular state body; information on the activities of state bodies in the media, in particular, on the websites of certain executive bodies. Let us also recall that the principle of publicity of public service to a certain extent is carried out in some Decrees of the President of Ukraine, in particular in the Decree "On the strategy of state personnel policy for 2012-2020" [12], etc.

There are also many reasons to agree with the opinion of $\mathrm{O}$. Amosov and $\mathrm{N}$. Havkalova that "in order for the transformation of public administration to take place, it is necessary to fulfill several conditions. First of all, it concerns the formation of an institutional control in the society, where actually at the same time there are several models of interaction and social segments: solidarity society, consorts, convections and legal social state" [13, p. 17].

The opinion of the authors of the "Encyclopedic dictionary of public administration" [11] that public administration is the maximum openness in the implementation of public policy is quite appropriate: if public policy is carried out through public activity, then such activity is public administration [11, p. 605]. In this context, the idea of adopting a special code on public service in Ukraine is appropriate.

The state-management elite is a relatively new, little scientifically developed term, which under the conditions of excessive bureaucratization of 
public administration, unfortunately, acquires a negative connotation.

First, the concepts of "political elite" and "state-management elite" are often unjustifiably mixed, associating them, although there is no special reason to do so.

Secondly, in order for such associations to be less tangible, public managers must be as depoliticized as possible. The task of a civil servant is to implement state policy as efficiently as possible, but the extent he/she values it as a person from the political point of view is a matter of his/her own human conscience and consciousness. In this regard, it is clear why in a number of states the status of a civil servant is politicized even in legal terms. And although politics and public administration (as well as political and public administration) have been closely intertwined since ancient times (Greece, Rome, China), it should be taken into account that politics is often explained as a kind of "pure", highlighted essence; as a specific activity of all subjects of social and political life, which regulates their relationship; as a way to achieve the relevant goals; as a set of issues and events of state and public life, etc. [14, p. 265]. That is, political and state activities still largely need to be "diluted", "delimited".

\section{REFERENCES}

1. Atamanchuk, G. V. (1997). Teoriya gosudarstvennogo upravleniya: kurs lektsiy [Theory of public administration: a course of lectures]. Moscow: Izd-vo Yuridicheskaya literatura [in Russian].

2. Kurits S. Ya., Vorobyev V. P. (2009). Bolezni gosudarstva. Diagnostika pa- tologiy sistemy gosudarstvennogo upravleniya i prava [Diseases of the state. Diagnostics of pathologies of the system of public administration and law]. Moscow: MGIMO (U) MID Rossii [in Russian].

3. Wiener N. (1968). Kibernetika ili upravlenie i svyaz $\mathrm{v}$ zhivotnom i mashine [Cybernetics, or control and communication in the animal and the machine]. ( $2^{\text {nd }}$ ed.). Moscow: Sovetskoe radio [in Russian].

4. Shemchushenko Yu. S., Babkin V. D., Horbatenko V. P. (Eds.). (2004). Politolohichnyi entsyklopedychnyi slovnyk [Politologic encyclopedic dictionary]. ( $2^{\text {nd }}$ ed., rev.). Kyiv: Geneza [in Ukrainian].

5. Khalipov V. F. (2005). Entsiklopediya vlasti [Encyclopedia of power]. Moscow: Akademicheskiy proekt; Kultura [in Russian].

6. Pavlenko V. V., Pavlenko V. L. (2017). Derzhavna sluzhba v Ukraini [Civil service in Ukraine]. Kyiv: DP "Vyd. dim "Personal" [in Ukrainian].

7. Ferro M., Afanasyeva Yu. (Eds.). (1989). 50/50 Opyt slovarya novogo myshleniya [50/50 Experience of the Dictionary of New Thinking]. Moscow: Progress [in Ukrainian].

8. Kurits S. Ya., Vorobyev V. P. (2009). Bolezni gosudarstva. Diagnostika patologiy sistemy gosudarstvennogo upravleniya i prava [Diseases of the state. Diagnostics of pathologies of the system of public administration and law]. Moscow: MGIMO (U) MID Rossii [in Russian].

9. Fedorov S. Ye. (2012). Pryntsyp hlasnosti u derzhavnomu finansovomu kontroli: mezhi transformatsii [The principle of publicity in public financial control: the limits of transformation]. Forum prava - Law Forum, 4, 963-969 [in Ukrainian].

10. Andriiv N. M. (2015). Orhanizatsiia derzhavnoho upravlinnia innovat- 
siinym rozvytkom vitchyznianoho pidpryiemstva u systemi vnutrishnoi torhivli [Organization of state management of innovative development of the domestic enterprise in the system of internal trade]. Hlobalni ta natsionalni problemy ekonomiky - Global and national problems of the economy, 4, 274-279 [in Ukrainian].

11. Kovbasiuk Yu. V., Troshchynskyi V. P., Surmin Yu. P. (Eds.). (2010). Entsyklopedychnyi slovnyk $\mathrm{z}$ derzhavnoho upravlinnia [Encyclopedic Dictionary of Public Administration]. Kyiv: NADU [in Ukrainian].

12. Ukaz Prezydenta Ukrainy "Pro stratehiiu derzhavnoi kadrovoi polityky na 2012-2020 roky" : vid 1 liutoho 2012 roku, № 45/2012 [Decree of the President of Ukraine "On the Strategy of the State Personnel Policy for 2012-2020" from February 1 2012, № 45/2012]. zakon.rada.gov.ua. Retrieved from http://zakon1.rada.gov. ua/laws/show/45/2012 [in Ukrainian].

13. Amosov O. Yu., Havkalova N. L. (2016). Symbioz instytutsiinykh zasad ta arkhetypiky publichnoho upravlinnia [Symbiosis of institutional foundations and archetype of public administration]. Publichne uriaduvannia Public administration, 2 (3), 16-22 [in Ukrainian].

14. Khalipov V.F. (1997). Vlast. Kratologicheskiy slovar [Power. Cratological dictionary]. Moscow: Respublika [in Russian].

\section{СПИСОК ВИКОРИСТАНИХ ДЖЕРЕЛ}

1. Атаманчук Г. В. Теория государственного управления: курс лекций. - М.: Юрид. лит., 1997. 512 c.

2. Курии, С. Я. Болезни государства. Диагностика патологий системы государственного управления и права: монография / С. Я. Куриц, В. П. Воробьев. - Моск. гос. ин-т междунар. отношений (ун-т) МИД России. - М.: МГИМО (У) МИД России, 2009. - 472 с.

3. Винер Н. Кибернетика. - 2-е изд.: пер с англ. "Советское радио”. - М., 1968. - $521 \mathrm{c}$.

4. Політологічний енциклопедичний словник / упоряд. В. П. Горбатенко; за ред.: Ю. С. Шемчушенка, В. Д. Бабкіна, В. П. Горбатенка. 2-ге вид. допов. і переробл. - К.: Генеза, 2004. - 736 c.

5. Халипов В. Ф. Энциклопедия власти. - М.: Академ. проект; Культура, 2005. - 1056 c.

6. Павленко В. В., Павленко В. Л. Державна служба в Україні: підручник. - К.: ДП “Вид. дім “Персонал”, 2017. -510 c.

7. 50/50 Опыт словаря нового мышления / под ред. М. Ферро и Ю. Афанасьева. - М.: Прогресс, 1989. $560 \mathrm{c}$.

8. Курии С. Я. Болезни государства. Диагностика патологий системы государственного управления и права: монография / С. Я. Куриц, В. П. Воробьев. - Моск. гос. ин-т междунар. отношений (ун-т) МИД России. - М.: МГИМО (У) МИД России, 2009. - 472 с.

9. Федоров C. $C$. Принцип гласності у державному фінансовому контролі: межі трансформації // Форум права. - 2012. - № 4. - С. 963-969. [Електронний ресурс]. - Режим доступу: archive.gov.ua/ejourncls/ EP/2012-4/12 tcekmp.pdt25

10. Андрії Н. М. Організація державного управління інноваційним розвитком вітчизняного підприємства у системі внутрішньої торгівлі // Глобальні та національні проблеми економіки. - 2015. - Вип. 4. - 274279 c. 
11. Енциклопедичний словник 3 державного управління / уклад.: Ю. П. Сурмін, В. Д. Бакуменко, А. М. Міхненко та ін.; за ред. Ю.В.Ковбасюка, В. П. Трощинського, Ю. П. Сурміна. - К.: НАДУ, 2010. - $820 \mathrm{c}$.

12. Указ Президента України "Про стратегію державної кадрової політики на 2012-2020 роки” від 1 лютого 2012 р. № 45/2012 [Елек- тронний ресурс]. - Режим доступу: http://zakon1.rada.gov.ua/laws/ show $/ 45 / 2012$

13. Амосов О. Ю., Гавкалова Н. Л. Симбіоз інституційних засад та архетипіки публічного управління // Публічне урядування. - Вип. № 2(3), червень 2016. - С. 16-22.

14. Халипов В. Ф. Власть. Кратологический словарь. - М.: Республика, 1997. - 431 c. 